\title{
The Analysis of the Mass Communication and the Moral Education Function of Chinese Commonweal Advertising
}

\author{
Hua Shang \\ Guangzhou Vocational College of Science and Technology \\ Guangzhou, 510550, China \\ Shanghua139@163.com
}

\begin{abstract}
This paper analyzed all kinds of mass communication function of commonweal advertising, it listed a large number of successful cases to interpret the commonweal advertising in the dissemination of positive life elements, survival philosophy, moral values and norms, and it promoted the harmonious development of the society as well as the important contributions; also the "the harmony between man and nature", the importance of family ethics, loyal to the nation, full of charity "benevolence", human and social harmony and progress of five demonstrated highlights and heritage education in Chinese excellent traditional moral values in commonweal advertising.
\end{abstract}

Keywords-component; commonweal advertising; mass communication; effect of moral education

\section{SUMMARY OF COMMONWEAL ADVERTISING}

The commonweal advertising is to provide service for commonweal, public welfare; it is an advertising communication activity for the purpose of promoting conducive to social morality, behavior norm and ideology [1]. The commonweal advertising is also called "public service ads", topics are all about public concerns and public responsibilities; it aims at the hot social issues in reality, and it becomes one of the most important parts of social commonweal enterprise, and it has a very special sociality.

The commonweal advertising first appeared in early 40's of twentieth Century in America, also known as the public service advertising, morality advertisement. Due to some serious social problems and environmental problems of high-speed development of the industrial revolution, the commonweal advertising was born with purposes of communication, propaganda, enlightenment, and persuasion as the times required, and it later gradually spread to Europe, Asia, and all over the world, and it became more and more influential.

The earliest commonweal advertising in China was released in 1978 in CCTV with strong political and military purposes. Gui Zhou TV in 1986 launched Chinese the first professional creative commonweal advertising -- "save water", it marked the symbolic birth of the modern commonweal advertising of our country; CCTV in 1987 founded "advertised" column, broadcast the commonweal advertising in prime time, the word "the commonweal advertising" began to win support among the people. After more than 20 years, the commonweal advertising is now on a planned, organized, full-range rapid development stage under government leadership, extending media from first TV to newspapers, periodicals, broadcastings, signs, networks, WeChats, etc., and the theme and content are more and more rich and varied.

\section{SOCIAL COMMUNICATION FUNCTION OF THE COMMONWEAL ADVERTISING}

The commonweal advertising advocates healthy social trends, correct views of life, values, norms of behavior with strong affinity; it makes people feel a heartfelt admiration. Just as the spring breeze, it brings the understanding between people, and it shows conscientious distinction between real and fake, good and evil, beauty and ugliness, true and false, it makes people feel warm and comfortable. Its irreplaceable roles are in the following six aspects:

\section{A. Promote and incentive effect}

The commonweal advertising stimulates public national spirit and patriotic enthusiasm; it advocates social morality, occupation morality, traditional virtue; it not only has full of love, virtue, civilization, human praise, but also has a great stimulation to the public. For example, Shanghai Feng Zikai commonweal advertising pictured simple harmony and artistic conception. The poem "to pine above the house, to raise generations with the spring bird" showed particularly China spirit. With so harmonious scene, then with "morality China" title as one of the "Chinese dream" series, and with the head on Chinese style and Chinese pursuit, it made the old work a great impact [2]. Another example: Hebei TV broadcasted a commonweal advertising "to resist great flood" in 1996. In this advertisement, a People's Liberation Army senior commanders braving the tempestuous waves rescued people, he held a child and fought the wind and waves hit, and transferred the child to a safety zone regardless of personal safety; it reflected the scenes of the people's Liberation Army to forget about one's own safety, as well as emergency rescue and disaster relief, the profound friendship with civilians; it received strong social impacts 
and created positive effects on army-civilian relationships after broadcasting.

\section{B. Guidance and enlightenment}

The commonweal advertising shows prominent role in culture and education. The public accepts advertisement concept through the interpretation process of thoughts, ideas, and value orientation [3]. The commonweal advertising's value guidance and the enlightened function are through the "appreciation" influence process unconsciously, and therefore more easily penetrate into the spiritual world. A commonweal advertising in CCTV broadcast said: "in fact, parents are the best teachers for children." It showed dutiful moments of the daughter-in-law and mother-in-law; daughter-in-law washed feet for old mother-in-law. Her son saw it inadvertently, and he silently imitated his mom, quietly to bring footbath water, washing feet for his mother... Young hearts under the influence of his mother's filial behavior produced unimaginable virtue leap. With ordinary theme, ingenious creativity, and touching effect, this commonweal advertising exceeds one's expectations, and well received by the public. There are also many excellent "stressing civilization, establish new trends" commonweal advertisings vividly interpret "Chinese dream" and other contemporary themes, and they play a positive role of enlightenment to lead society and promote the positive wind righteousness.

\section{Warning and admonishing function}

With the rapid development of modern industry, it brought convenience and benefits to human beings, it also caused problems and endanger, such as traffic congestion, environmental pollution, ecological imbalance caused natural disasters. In view of this situation, warning and exhortatory public interest advertising were also increased accordingly. For example, after Guizhou TV "save water" commonweal advertising broadcasted, the residents' water consumption decreased than the same period previous year 470,000 tons [4]. Other examples of the tree planting day series commonweal advertisings slogans "cherish the green environment, protect human survival space," "except the photos, what all don't take away anything else; except footprints, don't leave anything else" were all generally with a warning or admonition, making people more aware that the correct attitude was not getting, but giving for the common homeland; Chinese dream should be a saving resources, and full of green dream.

\section{Call and advice role}

Call and advice were commonweal advertisement's unique appeal to the public, they also cherished and cared for social vulnerable groups. A call for the whole public attention for the empty nest elderly people "when you listen, you let his lonely heart light again, your eyes give him strength to overcome annual rings, your hands raise wings for him to go after sunset, care for the elders, let the home no longer become eternal dream" deeply touched the hearts of people. On the other hand, there were many advices to get rid of the bad habits, such as Hebei TV station's commemorating World Health Day broadcast, "we can lose weight, but not lost life" was a commonweal advertisement advice for the demands of public health protection.

\section{Praise and lash effect}

Morality is a symbol of social civilization, and China is an ancient civilization country; morality plays an important role in the hearts of people. CCTV "advertisement" once played a commonweal advertisement, the picture showed "the hanging fish viceroy" who refused bribe in the ancient time, subtitle appeared "anti-corruption, have a niche in the temple of fame" at the end of story. Advertisement used a metaphor approach through the establishment of a noble character to praise example and educate the public.

In order to face the bad phenomenon of certain morality community declined, egoistic, harming others to benefit oneself, the commonweal advertisement "criticism and castigate," had the purpose of appealing advertisement to play the supervisory role of public opinion, and to urge the public to overcome the bad behavior, as well as to maintain and to create a good social environment. For example, although with euphemism the advertising "picked up your conscience from the trash can" criticized and lashed those littering or without garbage classification delivery.

\section{E. Art and inspiration}

The commonweal advertisement brings visual enjoyment with beautiful pictures; the process of feeling beauty that let it come inside is the process of letting the mind from restlessness to a sooth harmony. A Shandong winning commonweal advertisement was an unforgettable masterpiece in the year 1997. At the beginning, a branch of the apple flower filled up the screen, then flowers withered, green leafy branches bore an apple, it became bigger and bigger, and eventually a huge delicious apple. The fruit then became hidden, and bore two small apples, and then fade out again, and bore four small apples, after several times fade in and out, fruit branch was full of tiny bad apples. At this time, an overwhelmed apple branch was broken with a "Kacha" sound -- a picture frame stayed still. There was a profound voiceover in the distance "humans need to control themselves." With enrichment and exquisite metaphor, the art could be ten times shorten the time and space, and could a hundredfold or more to increase appeal and persuasion [5].

The commonweal advertising uses various artistic means to strengthen the theme in order to spread ideas to touch the soul, to sublime value concept in the public mind, and to covert a one-time behavior to spontaneous conscious lifetime behavior. Through the dissemination of commonweal advertising, it would completely solve the problem in the deep soul.

\section{THE COMMONWEAL ADVERTISING IS THE BIGGEST AND THE BEST WAY OF MORAL EDUCATION IN CLASSROOMS}

For individuals, the commonweal advertising's moral education is for the public moral quality; for the society, the commonweal advertising moral construction mission is based on the reality of social criticism and moral status. The dissemination of information can meet the public "sublime desire." It promotes rational social norms. It guides people's moral practice, with sharp eyes it profoundly grasps the 
current situation of the development, and use the short, concise and comprehensive ways for flagship guidelines, and it becomes the largest class of moral education, and moral norms "guide" in order to achieve the individual moral development and social civilization coordination win-win results.

From ancient to modern times, human is the creator of culture, but in the fast pace development of the economy, with the exposure of various social problems, human desires continue to enlarge, thus it gradually lost the moral standards. This requires the use of some power constraints to prevent the alienation phenomenon of culture. Social network is a kind of universal binding force, informal norms, including cultures, customs, ethics, morality, ideology and other invisible power constraints of human behavior. We can say that social network is an important part of social structure, and ethics is the core of the society. Because the ethics refers to human behavior in the context of the value judgment, is generally regarded as a kind of relationship, a tool to establish and regularly maintain people's social order [6]. The British historian Arnold Joseph Toynbee once said in "outlook twenty-first Century": Chinese culture must have a spirit to support more than one billion population. The stable structure in this culture is ethic [7]. Indeed, this ethical value helps to improve national faith in ancestor worship. Therefore, society needs to strengthen the cultivation of personal moral accomplishment. Personal moral qualities directly affect the social morality, occupation ethics, family virtues, world outlook and concept of honor and disgrace, morality education is conducive to the promotion of social morality, it is the foundation and fundamental of social morality construction.

\section{CHINA OUTSTANDING MORAL IDEAS IN THE COMMONWEAL ADVERTISEMENT HIGHLIGHTS AND EDUCATION VIRTUE}

As everyone knows, Chinese traditional culture spirit is supported by moral ethics. The commonweal advertisement is ethics in reality, it is the outline of Chinese spirit of traditional culture, is also the most accurate convey of ethics. Ethics as the superstructure and ideology of the society concerns most the harmonious development of man and man, man and society, man and nature; it is the full-dimension concern of real social life. In the long history development, while eliminating the feudal dross the traditional Chinese ethics have drawn a lot of its modern value essence, embodied in the following five categories:

\section{A. "The harmony between man and nature " of environmental ethics view}

Man and nature coexist in mutual love is a basic concept China traditional cultural spirit. Various schools all have " the harmony between man and nature " as the starting point and destination to reveal the unity of man and nature, and provide intelligence for human survival and development. Confucianism and Taoism have similar approach in this aspect. Confucianism emphasizes the benevolence in nature; Taoism emphasizes that the harmonious society is the unity of man and nature; it is the adaptation of natural. But in modern society, people's pursuit of the ideal of so-called happiness is the unbridled plunder, and even their own surviving earth. So the idea of "harmony between man and nature" of environmental morality has timely and profound significance for the depreciated natural environment towards society.

\section{B. Attention to family status of family ethics view}

Ernst Cassirer mentioned in the book "people analysis": Chinese is the standard of ancestor worship; you can study all basic characteristics and implications of ancestor worship there. Different theological system formed different national psychology. China is an ethical standard, family oriented state. This is different from ancient Greece which emphasizes the "social" of different gods pedigree, China makes "genealogy" as the foundation, emphasizes a kind of "family law". "All the species are created by god, all the people are created by ancestor." It is because of this history, China has a special affection for "family".

And the family essence is based on ethics and blood. Family means a protection of "consciousness and sensibility," it is also a destination of spirit. At the same time family is a cell of society. Family ethical relations appear in all aspects of family life, and they reflect a strong humanity. A good family moral and ethical relationship always play a positive role in family relationships, it makes an important contribution to the stability and development of society.

\section{Loyal to the nation's humanism ethics view}

"People-oriented" is a basic understanding of human in Chinese inherent culture, as a consanguineous patriarchal relation, it is a foundation of the rich colors of the collective and nationalism. Confucian's "people-oriented" theory claims the ethical and political relations as the core and basic issue of society. The value of life lies in the "regulating the family, the country and the world," it requires everyone's selfless, having group consciousness and sense of responsibility. Embodied in the moral cognition, it focuses the training on the value, emphasizes on a collective concept of social, grace, selflessness, clarity, justice. These are all basic contents in the Chinese culture values system.

\section{Full of charity "benevolence" humanitarian morality view}

Many works of contents by Confucius, Mencius and other thinkers could be read as the commonweal advertisement, they were a matter of public interest, and were for the public and for the people; "the Analects of Confucius" said: "the benevolent, love others to gain love back, forgive others to let others forgive oneself." Confucius stressed that people should sympathize with others, care, love, and to consider others in one's own place. He promoted mutual love, value people, have mercy, help others, place oneself in others' position for the sake of others; benevolence was the core idea and the primary value of Confucianism, "benevolence" spirit was not only the basic principle of morality, but also an ideal personality and supreme principles of ethics in Chinese culture. Benevolence person has the great sense of responsibility. The Chinese nation grew up and prospered under this great 
love. Just as Bertrand Russell pointed out in "The Problem of China": the traditional Confucian moral character naturally and successfully created a graceful, refined and courteous nation [8].

Charity and mercy reflect the commonweal advertisement in nature, function and degree on helping social vulnerable groups and emergency rescue missions. It advocates for helping flood and other causes of refugee, carrying forward the humanitarian spirit, and giving generous assistance.

\section{E. "Harmonious" development concept of the world view}

"Harmony" philosophy was not only adopted by ancient Chinese thinkers as a philosophical research category, but also was applied to the master plan of running a country. In China traditional culture of "appreciate harmony", "cooperation will benefit both" political thought; the essence and soul of the issue that the best interests of the country is "peace reigns over the land", "Peace in the world" system is the worldview. "Harmony" is another fundamental difference between Chinese traditional culture and western culture. The influence of a middle course in China culture is profound; it is an advanced philosophy as a mediator of social contradictions, so as to achieve the neutralized state. This thought keeps harmonious interpersonal relationship, and pays attention to achieve and to maintain harmonious situation. Harmony is one of the best state of survival and development, it is the ideal goal pursued by humans [9].

In today's world, "harmony" is not only reflected in between man and nature, man and man relationship, but more reflected in the relationships between nations. "Harmonious world" is a great concept of global political theory, law, and the construction of international relationships which is based on traditional Chinese culture's system view and integrated view; it has not only solved the problem of Chinese development road issues, but also has established the guiding principle of global international political ethics and international order; only the harmonious coexistence among different countries, and to achieve democracy in international relationships can build a harmonious world lasting peace, common prosperity[10].

The goal of above classification is to more clearly convey the conjunction point between the essence of traditional Chinese morality and the commonweal advertisement content. In fact, many Chinese culture moral and ethical thinking are reflected in more aspects. Growing up in the deep cultural accumulation environment Chinese commonweal advertisement will pay a key role and create a strong effect in enhancing people's moral consciousness, founding value standards.

\section{THE CONCLUSION}

The social communication and moral education function of the commonweal advertisement are not only a theoretical issue, but a more the realistic issue; the commonweal advertisement is a cast project to play the heart work, in order to moisten things silently to spread effect, it should find the conjunction point between moral education and communication performance. The profound traditional culture and excellent spirit quality create a suitable humanity environment to advocate commonweal advertisement. Chinese culture has its unique language and multitude cultural classics to benefit the world science and technology. Brilliant literary art, full of wisdom philosophy of religion, as well as complete and profound moral ethics are all rare Chinese cultural resources and spiritual treasures for commonweal advertisement development. People are often proud with Chinese cultural, with a long history as the capital, but at the same time when pride and showing off, China traditional culture and spirit are gradually in the direction of loss, ethics has been twisted off; therefore, the social communication function and the moral education historical mission in commonweal advertising carry profound meanings and responsibilities.

\section{REFERENCES}

[1] Ma Yumei, Zhou Yunli "the public service advertisement social value" "academic exchange" 2002, 2 issue.

[2] Zhu Binsheng "Civilized new practices to promote commonweal advertisement and to have a brilliant future -- an appreciation of Shanghai Fang Zikai series" "stressing civilization, establish new trends " commonweal advertisement, Sichuan Civilization Network 2013-07-18.

[3] Li Bin: "Media literacy", Xinhua press 2006 edition, page 252.

[4] Jiang Tao "Research of commonweal advertising social function" of "Jilin radio and Television University" 2005, 3 issue.

[5] "The commonweal advertising design description": 2010-06-09 source: Zhuzhou advertising, author: Zhuzhou advertising company http://www.sanyuan163.com/guandianjijin/zhuzhouView/2010/06/09/ 348.html.

[6] Li Hao, He Jiang, " The commonweal advertising ethics inheritance" "Reporter 's cradle" 2009, 12 issue.

[7] Arnold Joseph Toynbee, 1889- 1975, "Outlook twenty-first Century " It was published after he organized the basis of dialogues with Japanese scholar Ikeda Oku's in London in 1972.

[8] Russell, Qin Yue translated "The Problem of China" Xue Lin press, 1996.

[9] Cui Yue, Li Dawei "Inheritance of domestic commonweal advertising ethics" "development" in 2009, 1 issue.

[10] Baidu encyclopedia "harmonious world" http://baike.baidu.com/view/399989.htm 2014.3.28. 